\title{
Depressive Symptoms and Relationship Between Genders: Differences in Young Adults in a Randomized Clinical Trial ${ }^{1}$
}

\author{
Mariane Ricardo Acosta Lopez Molina \\ Universidade Católica de Pelotas, \\ Pelotas-RS, Brazil \\ Ricardo Azevedo da Silva \\ Universidade Católica de Pelotas, \\ Pelotas-RS, Brazil
}

\author{
Karen Jansen \\ Universidade Católica de Pelotas, \\ Pelotas-RS, Brazil \\ Miguel Bezerra dos Passos \\ Universidade Católica de Pelotas, \\ Pelotas-RS, Brazil
}

\author{
Ricardo Tavares Pinheiro \\ Universidade Católica de Pelotas, \\ Pelotas-RS, Brazil \\ Luciano Dias de Mattos Souza \\ Universidade Católica de Pelotas, \\ Pelotas-RS, Brazil
}

\begin{abstract}
Depression has a high prevalence in the general population, especially among women. There is no consensus in the scientific literature about differences between men and women in the manifestations of depressive symptoms, nor about psychotherapy indications according to gender. This research aimed to verify differences in depressive symptoms and symptoms improvement between young adult men and women with current Major Depressive Disorder and to identify differences between two brief Cognitive Psychotherapy models. Randomized clinical trial in which participants were randomized between: Cognitive Behavioral Therapy and Narrative Cognitive Therapy. Depressive symptoms pre and post-intervention were evaluated using the Hamilton Depression Rating Scale. The sample was composed of 25 men and 95 women. Genital symptoms and insight were significantly different between genders. Concerning improvement in symptoms according to the psychotherapy model, CBT presented a trend toward being more effective in men. Therefore, the symptoms and improvement in depressive symptoms are manifested differently between genders.
\end{abstract}

Keywords: symptoms, depression, gender, young adults, cognitive therapy

\section{Sintomas Depressivos e Relação entre os Gêneros: Diferenças em Adultos Jovens de um Ensaio Clínico Randomizado}

Resumo: A depressão apresenta elevada prevalência na população geral, especialmente entre as mulheres. Não existe consenso na literatura científica a respeito de diferenças das manifestações de sintomas depressivos entre homens e mulheres, bem como, quanto à indicações de psicoterapias conforme o gênero. O objetivo deste estudo foi verificar as diferenças na sintomatologia depressiva e melhora dos sintomas em homens e mulheres adultos jovens com Transtorno Depressivo Maior e identificar as diferenças entre dois modelos de Psicoterapia Cognitiva. Em ensaio clínico, os participantes foram randomizados entre: Psicoterapia Cognitivo Comportamental e Psicoterapia Cognitiva Narrativa. A sintomatologia depressiva pré e pós intervenção foi avaliada pela Hamilton Depression Scale. Participaram do estudo 25 homens e 95 mulheres. Os sintomas genitais e de consciência foram significativamente diferentes entre os gêneros. Quanto à melhora dos sintomas de acordo com o modelo psicoterapêutico, a PCC apresentou uma tendência a ser mais eficaz entre os homens. Sendo assim, é possível observar que a sintomatologia e a melhora dos sintomas depressivos manifestam-se diferentemente entre os gêneros.

Palavras-chave: sintomas, depressão, gênero, jovens, terapia cognitiva

\section{Síntomas Depresivos y la Relación entre los Géneros: Diferencias en Adultos Jóvenes de un Ensayo Clinico Randomizado}

\begin{abstract}
Resumen: La depresión tiene una alta prevalencia en la población general, especialmente entre las mujeres. No hay consenso en la literatura científica sobre las diferencias en las manifestaciones de síntomas depresivos entre hombres y mujeres, ni sobre las indicaciones de las psicoterapias según el género. Este estudio tuvo como objetivo determinar las diferencias en los síntomas depresivos y la mejora de los síntomas en hombres y mujeres jóvenes adultos con Trastorno Depresivo Mayor actual y comprobar las diferencias entre los dos modelos de psicoterapia cognitiva. En este ensayo clínico, los participantes fueron asignados aleatoriamente entre: Psicoterapia Cognitivo Comportamental y Psicoterapia Cognitiva Narrativa. Los síntomas de depresión pre y post intervención se evaluaron mediante la Escala de Depresión de Hamilton. La muestra estuvo constituida por 25 hombres y 95 mujeres. Síntomas genitales y de conciencia fueron significativamente diferentes entre los géneros. En cuanto a la mejoría de los síntomas de acuerdo con el modelo psicoterapéutico, el PCC tuvo una tendencia a ser más eficaz entre los hombres. Es posible observar que la sintomatología y la mejora en los síntomas depresivos se manifiestan de forma diferente entre géneros.
\end{abstract}

Palabras clave: síntomas, depresión, género, jóvenes, terapia cognitiva

\footnotetext{
${ }^{1}$ Article derived from the doctoral dissertation of the first author, under the advice of the sixth author, defended in 2013 in the Graduate Program in Health and Behavior of the Universidade Católica de Pelotas.

Support: Foundation for Research Support of the State of Rio Grande do Sul - FAPERGS (Grant \# 10/0055-0) and Coordination for the Improvement of Higher Education Personnel - CAPES (Grant \# 23038.001671/2012-16).

2 Correspondence address: Mariane Ricardo Acosta Lopez Molina. Rua Gonçalves Chaves, 373-411C, Centro. CEP 96015-560. Pelotas-RS, Brazil. E-mail: mariane_lop@hotmail.com
}

Women are more prone than men to experience depressive episodes. This distinction might be based on biological and hormonal differences, particularly concerning the prevalence of Major Depressive Disorder (MDD) (Kennedy, Einstein, \& Downar, 2013; Kessler, 2003). Women also report higher depressive symptoms levels, suggesting a difference between genders in expressing depressive symptomatology (Molina et 
al., 2014). To date, controversies are still more common than established conclusions in the literature.

Concerning gender differences in psychotherapeutic interventions, an anti-male vision of psychotherapy can be noted in men (Englar-Carlson, 2006), meaning that they consider men that seek help due to depressive symptoms to be more feminine (McCusker \& Galupo, 2011). The gender role schema theory hypothesizes that cultural influences shape an individual's model of masculinity and femininity and potentially guide what are considered "acceptable" and "unacceptable" enactments of gender (Bem, 1981).

In terms of psychotherapy, the key interventions for depression in primary care settings are treatment with generic antidepressant drugs and brief psychotherapy. Thus, combined intervention indicates enhanced rates of recovery when compared with medications alone (Corruble et al., 2016; Hollon et al., 2014). CBT has shown better results in treating depression than traditional medical interventions and other psychotherapies, even with young adults (Nardi, Francesconi, Catena-Del'Osso, \& Bellantuono, 2013). It also presents lower costs in relation to pharmacological interventions (Hollon, Steward, \& Strunk, 2006) and a preventive effect against recurring depression, surpassing the effects obtained with antidepressants (Vittengl, Clark, Dunn, \& Jarrett, 2007). The general CBT model does not make specific references or predictions regarding gender socialization. While several models could potentially be applied to male depression, individuals with strong cognitive and behavioral focus may be particularly compatible with the general CBT model (Spendelow, 2015). Some authors indicate that behavioral interventions might be particularly suitable for men, due to their practical and tangible nature (Brooks, 2010; Englar-Carlson, 2006). Usually, psychosocial intervention models do not consider cultural gender differences.

Narrative cognitive therapy (NCT) understands the narrative as a fundamental element to understand how humans construct and organize knowledge and experiences (Gonçalves \& Machado, 1999). Aragão, Coutinho, Araújo, and Castanha (2009) found that both genders have different social representations of depression. Therefore, their experience of it may also be different. Nevertheless, there is no specific indication of guidelines in the field of psychotherapy that indicates a psychotherapy model based on the gender of the patient.

Although themes involving symptomatology, psychotherapeutic interventions and depressive symptoms improvement are present in the literature, a lack of studies specifically about differences between genders can be noted in young adult clinical samples. Hence, this investigation aimed primarily to investigate differences in depressive symptoms between men and women diagnosed with MDD in a young adult clinical sample (18-29 years old). A secondary aim was to verify the impact of gender on depressive symptoms improvement after treatment with cognitive psychotherapy (CBT or NCT) and verify improvement differences between genders according to the therapeutic model (CBT or NCT).

\section{Participants}

\section{Method}

This is a randomized clinical trial, nested in a larger study that aimed to evaluate the effectiveness of brief psychotherapies in improving depressive symptoms in young adults. A conveqience sample was obtained; local media advertised the research and posters were put in schools, universities, and health centers. This study included 120 (95 women and 25 men) drug-free young adults, aged 18 to 29 years, without current suicide risk, who had a clinical diagnosis of MDD according to the Structured Clinical Interview for DSM (SCID) (Del-Ben et al., 2001).

\section{Instruments}

The translated version of the Hamilton Depression Rating Scale (HDRS), usually used in Brazil. The ROC curve analysis identified the cutoff ( 9 points) to discriminate the presence or absence of depression, resulting in a sensibility and specificity of 90 and $91 \%$, respectively. The internal validity was investigated by factorial analysis and consistency of the items. It was observed that all 17 original items, except "Consciousness", presented psychometric quality to evaluate general depression, and that there were five dimensions underlying those 16 items: Depressed humor, Anorexia, Insomnia, Somatization, and Anxiety. All of them, except the last, showed homogeneity in their constructs (alpha coefficients between 0.66 and 0.78 ). The HDRS possesses adequate psychometric properties for use in the investigated population according to the adaptation study (Freire et al., 2014).

\section{Procedure}

Data collection. After having met inclusion criteria and agreeing to participate, patients received seven weekly sessions, each an hour long, and were randomized between two psychotherapy models. The manual for Cognitive Behavioral Therapy was grounded in the theory of Beck, Rush and Emery (1997), arguing that distorted or dysfunctional thinking (which influences mood and behavior) is common to all psychological disorders. Reality checks associated with thinking pattern changes lead to improvements in mood and behavior, helping the patients to adjust their basic dysfunctional beliefs. The manual for Narrative Cognitive Therapy (NCT) was structured based on the proposal of Oscar Gonçalves from the University of Minho (Portugal) and has the goal of restructuring personal narratives, giving new meaning to negative experiences. New interpretations are reintegrated into the individual's personal history with a new adjusted meaning (Gonçalves, 1998). In the clinical trial, senior psychology students conducted the interventions with the protocols proposed and were blinded to the intervention model.

Participants were surveyed regarding sociodemographic data (sex, age, education) and the economic indicator was measured using the National Economic Index (NEI) (Barros \& Victora, 2005). Depressive symptoms severity was assessed with the HDRS, consisting of 17 questions. The total score creates a discrete variable, where higher scores indicate greater severity (Hamilton, 1967). Evaluation of symptoms improvement in patients treated with the therapeutic models was considered through the delta score (difference between initial and final score of the HDRS).

Data analysis. All assessments were coded and data were entered into an Epi-Info 6.04d database and validated through double data entry (Dean et al., 1994). Statistical analysis was conducted with SPSS 21.0 software. Univariate analysis was performed using simple frequencies of the investigated variables. When evaluating HDRS items, symptoms 
were considered either present or absent, according to intensity $(0=$ absent; 1 or higher $=$ present $)$. Chi-square, Fischer's and Student's $t$ tests were used in bivariate analyses to describe differences between genders regarding the presence of depressive symptoms and the independent variables. Finally, the Mann-Whitney test was used to compare improvements in depressive symptoms according to the psychotherapy model. Significance levels were maintained at $p<.05$.

\section{Ethical Considerations}

Participants received information about the research objectives and signed a "Term of Free and Informed Consent". The project received approval from the ethics committee of the Catholic University of Pelotas, protocol n. 2009/24.

\section{Results}

For inclusion in the study, 282 individuals were evaluated and 162 did not meet the inclusion criteria, resulting in a final sample of 120 young adults. Twenty-five male subjects met the inclusion criteria, 22 started psychotherapy and 8 (36.4\%) dro-

Table 1

Gender Differences in Depressive Symptoms Assessed by HDRS pped out. Ninety-five female subjects met the inclusion criteria, 69 started psychotherapy and $15(21.7 \%)$ dropped out. However, dropouts were not statistically different between the genders. Most of the sample was composed of individuals aged 25-29 years $(43.3 \%)$, with over 12 years of schooling $(52.7 \%)$ and intermediate economic conditions (34.2\%). Both education $(p=.100)$ and economic condition $(p=.174)$ tended towards a significant difference in depressive symptoms between genders.

At baseline, the most prevalent symptoms were difficulties with work/activities and general somatic symptoms. When evaluated according to gender, the most prevalent symptoms in women were difficulties with work/activities and general somatic symptoms while, in men, they were difficulties with work/activities and early insomnia. In bivariate analysis, genital symptoms and insight were significantly different between genders. Genital symptoms were reported by $70.5 \%$ of women, while $40 \%$ of men reported such symptoms $(p=.009)$. Concerning symptoms related to illness insight, more men $(12 \%)$ attribute their condition to external causes when compared with women $(1.1 \%)(p=.028)$. Regarding HDRS scores, symptoms improved from baseline to post-intervention. However, these differences did not remain significant in relation to gender (Table 1).

\begin{tabular}{|c|c|c|c|c|}
\hline Variable & Total & Men & Women & $p$ value \\
\hline \multicolumn{5}{|l|}{ Depressive symptoms } \\
\hline Feelings of guilt ${ }^{\mathrm{a}}$ & $80(66.7)$ & $18(72.0)$ & $62(65.3)$ & .636 \\
\hline Suicide $^{\mathrm{a}}$ & $35(29.2)$ & $8(32.0)$ & $27(28.4)$ & .806 \\
\hline Insomnia early ${ }^{\mathrm{a}}$ & $89(74.1)$ & $21(84.0)$ & $68(71.6)$ & .305 \\
\hline Insomnia middle ${ }^{\mathrm{a}}$ & $75(62.5)$ & $13(52.0)$ & $62(65.3)$ & .251 \\
\hline Insomnia late ${ }^{a}$ & $74(61.7)$ & $14(56.0)$ & $60(62.3)$ & .644 \\
\hline Work and activities ${ }^{\mathrm{a}}$ & $116(96.6)$ & $24(96.0)$ & $92(96.8)$ & 1.000 \\
\hline Retardation $^{\mathrm{a}}$ & $15(12.5)$ & $4(16.0)$ & $11(11.6)$ & .513 \\
\hline Agitation $^{\mathrm{a}}$ & $45(37.5)$ & $12(48.0)$ & $33(34.7)$ & .251 \\
\hline Psychic anxiety ${ }^{\mathrm{a}}$ & $72(60.0)$ & $14(56.0)$ & $58(61.1)$ & .654 \\
\hline Somatic anxiety ${ }^{a}$ & $85(70.8)$ & $17(68.0)$ & $68(71.6)$ & .806 \\
\hline Somatic gastrointestinal ${ }^{\mathrm{a}}$ & $70(58.4)$ & $15(60.0)$ & $55(57.9)$ & 1.000 \\
\hline Somatic general ${ }^{\mathrm{a}}$ & $94(78.3)$ & $18(72.0)$ & $76(80.0)$ & .418 \\
\hline Genital symptoms ${ }^{\mathrm{a},{ }^{*}}$ & $77(64.2)$ & $10(40.0)$ & $67(70.5)$ & .009 \\
\hline Hypochondriasis $^{\mathrm{a}}$ & $10(8.4)$ & $1(4.0)$ & $9(9.5)$ & .686 \\
\hline Loss of weight ${ }^{\mathrm{a}}$ & $7(5.8)$ & $2(8.0)$ & $5(5.3)$ & .635 \\
\hline Insight ${ }^{\mathrm{a},{ }^{*}}$ & $4(3.3)$ & $3(12.0)$ & $1(1.1)$ & .028 \\
\hline HDRS score at baseline ${ }^{b}$ & $12.17(3.67)$ & $11.64(3.40)$ & $12.30(3.74)$ & .422 \\
\hline HDRS score at post-intervention ${ }^{b}$ & $8.59(5.34)$ & $8.56(4.79)$ & $8.60(5.49)$ & .974 \\
\hline
\end{tabular}

Note. ${ }^{a}$ Absolute and relative (\%) frequencies, $p$ value by Fisher; ${ }^{b}$ Mean and standard deviation $( \pm), p$ value by Student's $t$-test; *significant difference between genders. 
When evaluating differences in symptoms improvement according to psychotherapy model, there was a trend toward greater symptoms improvement among men treated with CBT. While men treated with NCT obtained an average improvement of $1.8(S D=3.3)$, those treated with CBT revealed an average improvement of $5.2(S D=4.5 ; p=.059$; Figure 1A). Among women, no differences were observed in symptoms improvement according to the psychotherapy model ( $p$ $=.753$; Figure $1 \mathrm{~B}$ ).
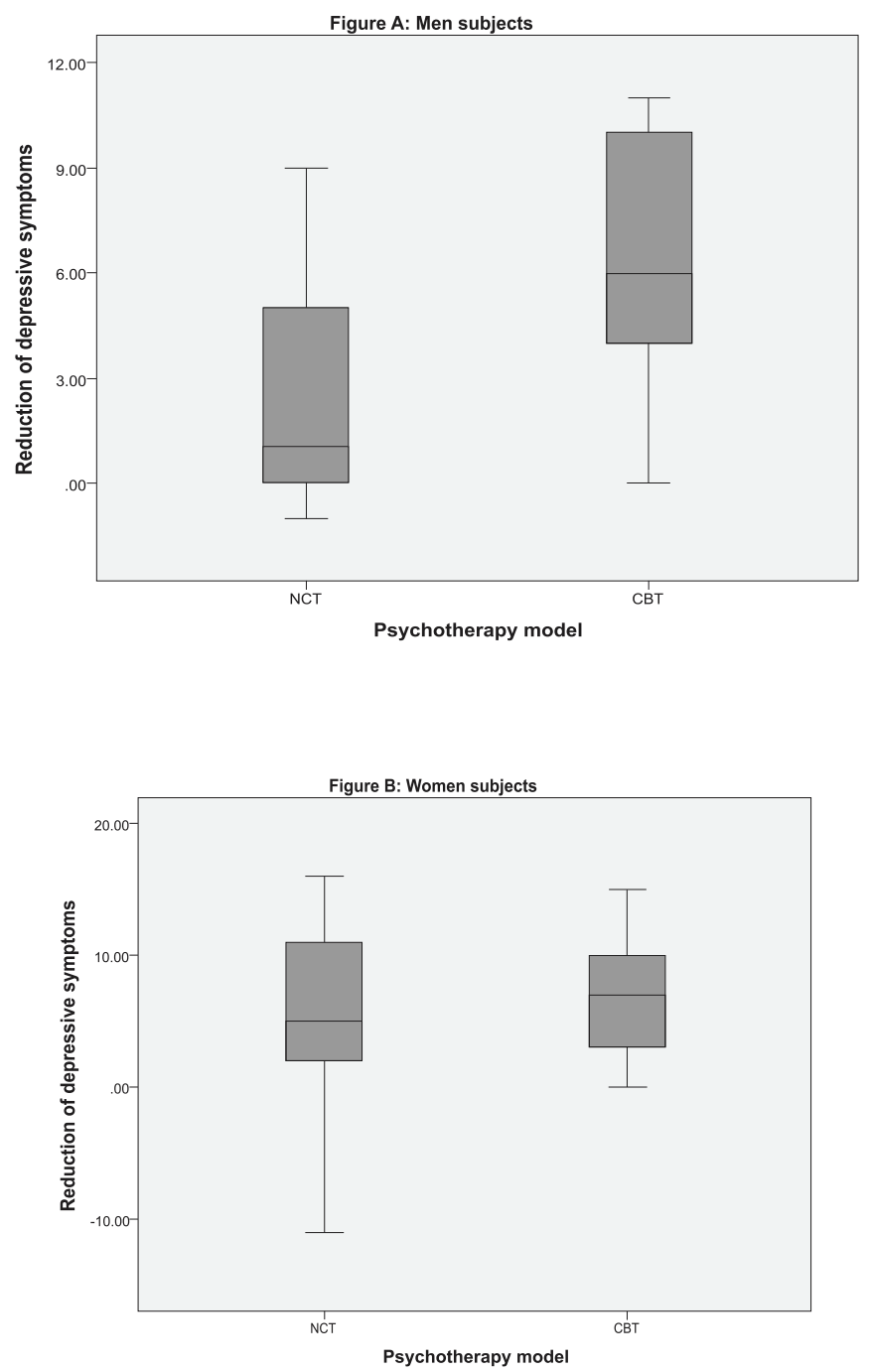

Figure 1. Reduction of depressive symptoms between psychotherapy models. Note. Figure A shows a trend towards greater reduction of depressive symptoms in the CBT when compared to the NCT ( $p=.059$ by Mann Whitney). The same was not observed in Figure B ( $p=.753$ by Mann-Whitney).

\section{Discussion}

Regarding the first aim of this study, which was to investigate differences in depressive symptoms between men and women diagnosed with MDD in a young adult clinical sample, two symptoms were significantly present in women when compared with men (genital symptoms and insight). Concerning differences between genders according to the psychotherapeutic model, there were no differences between genders, although men in CBT might have presented higher improvement than those in NCT.

Significant differences were observed between genders only in genital symptoms and insight. The increased risk of depressive symptoms in women since adolescence reflects a well-known data in the epidemiology of depression (Piccinelli \& Wilkinson, 2000; Rombaldi, Silva, Gazalle, Azevedo, \& Hallal, 2010). Regarding this topic, Justo and Calil (2006) cite possible explanations for this increased risk, such as sociocultural issues related to adverse experiences and psychological as well as physiological attributes associated with greater vulnerability to stressful events. In relation to genital symptoms affecting almost twice as many interviewed women when compared with men, the same was observed in a study about depressive symptoms in adults admitted to a general hospital (Dal Bó, Silva, Machado, \& Silva, 2011). This finding may be explained by the close relationship between the characteristic hormonal fluctuations of females and both affective dysregulation and vulnerability to depression. Such reasons also contribute to the risk of depression recurrence, mainly in young women (Koppers, Peen, Niekerken, Van, \& Dekker, 2011; Machado, Oliveira, \& Delgado, 2013).

These differences may also be explained by internal and external factors culturally typical of each gender. It has been observed that boys tend to externalize problems, which generates conflict with the environment, while girls lean toward internalizing problems, which is related to personal disorders (Agam, Tamir, \& Golan, 2015). This dysfunctional pattern can be extended throughout the development of both genders.

Regarding men attributing their depressive symptoms to external factors almost twice as much, such as bad food, climate, overwork, virus, need for rest, etc., this perception could be linked to how each gender deals with health alterations. For example, women appear to be more inclined to remember and report mood changes that have occurred in the past (Wilhelm \& Parker, 1994). It may also be justified by the way each gender represents its depressive state. Aragão et al. (2009), when researching about social representations of depression in adolescents, concluded that women represented depression through pain, sadness, unhappiness and described depressed people as worried, while men associated depression with anger and described depressed people as solitary. This reinforces the idea of depression manifesting itself in women in a more internalized form, while predominantly externalized in men. In fact, in a review about influence of gender on depression psychotherapies, the authors concluded that non-specific factors like openness, admitting the pathology, seeking help and treatment contribute to differences in results between genders (Parker, Blanch \& Crawford, 2011).

Another factor discussed in this research was depressive symptom improvement, where no significant differences between genders were found, like in a review about improvement in untreated depressive symptoms (Whiteford et al., 2013). In a study performed with depressed individuals receiving citalopram, however, improvement in symptoms measured by the Hamilton scale was greater among women than men. Organic gender aspects explained this difference, particularly the function of estrogen in women's serotonergic 
systems. Moreover, the authors emphasized that the whole context of childhood and adolescence, as well as cognitive and psychological factors are different between genders and may also contribute to the capacity of differential responsiveness to serotonin reuptake inhibitors (Young et al., 2009).

In terms of psychotherapy, studies reveal significant improvement in depressive symptoms after intervention with brief psychotherapy (Collado, Lim, \& MacPherson, 2016; Silva et al., 2016), as well as with brief psychotherapy plus medication when compared with medication alone (Bressi, Porcellana, Marinaccio, Nocito, \& Magri, 2010; Hollon et al., 2005, 2014). However, no differences between genders were addressed in the literature. Differences presented in this study's sample were restricted to smaller depressive symptoms improvement in men treated with NCT. This approach indicates that auto-narrative changes are an important part of psychotherapeutic success. Moreover, authors have highlighted the usefulness of narrating new experiences (like actions, thoughts and stories) during therapy, contrasting with the customer's inadequate auto-narratives (Cunha et al., 2012). Therefore, along with possible influence of biological aspects, it is also possible that the more humanistic experience during the constructivist process of NCT is more suitable to female depression representations (Gonçalves \& Machado, 1999).

Based on the literature data and the present study, it is suggested that the application of structured psychotherapeutic strategies like CBT in men is congruent with better treatment prognosis. It is known that the concrete techniques used in CBT can play an important role in relieving depressive symptoms (Nyer, Fisher, \& Farabaugh, 2016; Picardi \& Gaetano, 2014), since this model postulates that, when inadequate thoughts are fixed, acute distress and risk of subsequent return of symptoms are reduced (Beck, Rush, Shaw \& Emery, 1979). Furthermore, it is interesting for depression treatment protocols to consider the findings related to the presence of depressive symptoms in MDD patients. Certain intervention techniques may be more favorable based on gender.

This is the first investigation in a young adult population about depressive symptomatology, symptoms improvement and gender impact on psychotherapy models. Nevertheless, some limitations need to be addressed: the low generalization capacity of these findings, specifically due to the low number of men in the sample. This discrepancy between genders in numbers could be justified by stereotypical male beliefs, contributing to the reluctance in men to seek and involve themselves in a psychotherapeutic process. Furthermore, we did not investigate cultural factors that address constructs of masculinity. Another important limitation is that we did not evaluate clinical features such as duration of illness, duration of untreated illness or age at onset and hormonal factors.

There were advantages though: favorable conditions for evaluation, performed by previously trained psychologists, with a structured clinical interview and in an appropriate place, composed of individual rooms. Another positive point was that participants did not take medication, favoring the measuring of the psychotherapeutic process and symptoms improvement.

It can be highlighted that gaps remain in the expression of depressive symptoms between genders and its impact on psychosocial treatment. Nevertheless, among the few studies discussing this theme, it is a consensus that these differences are related to biological and psychosocial factors typical of each gender. Concerning psychotherapy, models that include behavioral and structured interventions may be more effective for males. Future investigations about this theme are needed to develop specific knowledge and improvements in diagnosis, therapeutic interventions and symptoms of individuals affected by MDD.

\section{References}

Agam, R., Tamir, S., \& Golan, M. (2015). Gender differences in respect to self-esteem and body image as well as response to adolescents' school based prevention programs. Journal of Psychology and Clinical Psychiatry, 2(5), 00092. doi:10.15406/jpcpy.2015.02.00092

Aragão, T. A., Coutinho, M. P. L., Araújo, L. F., \& Castanha, A. R. (2009). Uma perspectiva psicossocial da sintomatologia depressiva na adolescência [A psychosocial perspective of depressive symptoms in adolescence]. Ciência \& Saúde Coletiva, 14(2), 395-405. doi:10.1590/S141381232009000200009

Barros, A. J. D., \& Victora, C. G. (2005). A nationwide wealth score based on the 2000 Brazilian demographic census. Revista de Saúde Pública, 39(4), 523-529. doi:10.1590/ S0034-89102005000400002

Beck, A. T., Rush, A. J., \& Emery, G. (1997). Terapia cognitiva da depressão [Cognitive therapy of depression] (S. Costa, Trad.). Porto Alegre, RS: Artes Médicas.

Beck, A. T., Rush, A., Shaw, B., \& Emery, G. (1979). Cognitive therapy of depression. New York, NY: Guilford.

Bem, S. L. (1981). Gender schema theory: A cognitive account of sex typing. Psychological Review, 88(4), 354-364. doi:10.1037/0033-295X.88.4.354

Bressi, C., Porcellana, M., Marinaccio, P. M., Nocito, E. P., \& Magri, L. (2010). Short-term psychodynamic psychotherapy versus treatment as usual for depressive and anxiety disorders: A randomized clinical trial of efficacy. Journal of Nervous and Mental Disease, 198(9), 647-652. doi:10.1097/NMD.0b013e3181ef3ebb

Brooks, G. R. (2010). A transtheoretical model. In Beyond the crisis of masculinity: A transtheoretical model for male-friendly therapy (pp. 139-169). Washington, DC: American Psychological Association.

Collado, A., Lim, A. C., \& MacPherson, L. (2016). A systematic review of depression psychotherapies among Latinos. Clinical Psychology Review, 45, 193-209. doi:10.1016/j. cpr.2016.04.001

Corruble, E., Swartz, H. A., Bottai, T., Vaiva, G., Bayle, F., Llorca, P.-M., ... Gorwood, P. (2016). Telephone-administered psychotherapy in combination with antidepressant medication for the acute treatment of major depressive disorder. Journal of Affective Disorders, 190, 6-11. 
doi:10.1016/j.jad.2015.07.052

Cunha, C., Gonçalves, M. M., Hill, C. E, Mendes, I., Ribeiro, A. P., Sousa, I., Angus, L., Greenberg, L. S. (2012). Therapist interventions and client innovate moments in emotion focused therapy for depression. Psychoterapy, 49(4), 536548. doi:10.1037/a0028259

Dal Bó, M. J., Silva, G. S., Machado, D. F. G. P., \& Silva, R. M. (2011). Prevalência de sintomas depressivos em pacientes internados em enfermarias de clínica médica de um hospital geral no Sul de Santa Catarina [Prevalence of depressive symptoms in patients admitted to clinical sector in a general hospital in the South of Santa Catarina]. Revista da Sociedade Brasileira de Clínica Médica, 9(4), 264-268.

Dean, A., Brendel, K., Smith, D., Burton, A., Dicker, R., \& Sullivan, K. (1994). Epi-Info version 6.04d: A word processing database, and statistics program for epidemiology on microcomputers. Atlanta, GA: Centers for Disease Control and Prevention.

Del-Ben, C. M., Vilela, J. A. A., Crippa, J. A. S., Hallak, J. E. C., Labate, C. M., \& Zuardi, A. W. (2001). Confiabilidade da Entrevista Clínica Estruturada para o DSM-IV - Versão clínica traduzida para o português [Reliability of the Structured Clinical Interview for DSM-IV - Clinical version translated into Portuguese]. Revista Brasileira de Psiquiatria, 23(3), 156-159. doi:10.1590/S151644462001000300008

Englar-Carlson, M. (2006). Masculine norms and the therapy process. In M. Englar-Carlson \& M. A. Stevens (Eds.), In the room with men: A casebook of therapeutic change (pp. 1347). Washington, DC: American Psychological Association.

Freire, M. A., Figueiredo, V. L. M., Gomide, A., Jansen, K., Silva, R. A., Magalhães, P. V. S., \& Kapczinski, F. P. (2014). Escala Hamilton: Estudo das características psicométricas em uma amostra do sul do Brasil [Hamilton Scale: Study of the psychometric characteristics in a sample from Southern Brazil]. Jornal Brasileiro de Psiquiatria, 63(4), 281-289. doi:10.1590/0047-2085000000036

Gonçalves, O. F. (1998). Psicoterapia cognitiva narrativa: Manual de terapia breve [Cognitive psychoterapy narrative: Brief therapy manual]. Campinas, SP: Editorial Psy.

Gonçalves, O. F., \& Machado, P. P. P. (1999). Cognitive narrative psychotherapy: Research foundations. Journal of Clinical Psychology, 55(10), 1179-1191. doi:10.1002/(SICI)1097-4679(199910)55:10<1179::AID-JCLP2>3.0.CO;2-L

Hamilton, M. (1967). Development of a rating scale for primary depressive illness. British Journal of Social \& Clinical Psychology. 6(4), 278-296. doi:10.1111/j.2044-8260.1967. tb00530.x

Hollon, S. D., DeRubeis, R. J., Fawcett, J., Amsterdam, J. D., Shelton, R. C., Zajecka, J., ... Gallop, R. (2014). Effect of cognitive therapy with antidepressant medications vs antidepressants alone on the rate of recovery in major depressive disorder: A randomized clinical trial. JAMA
Psychiatry, 71(10), 1157-1164. doi:10.1001/jamapsychiatry.2014.1054

Hollon, S. D., Jarrett R. B., Nierenberg A. A., Thase M. E., Trivedi M., \& Rush A. J. (2005). Psychotherapy and medication in the treatment of adult and geriatric depression: Which monotherapy or combined treatment? The Journal of Clinical Psychiatry; 66(4), 455-468. doi:10.4088/JCP. v66n0408

Hollon, S. D., Steward, M. O., \& Strunk, D. (2006). Enduring effects for cognitive behavior therapy in the treatment of depression and anxiety. Annual Review of Psychology, 57, 285-315. doi:10.1146/annurev.psych.57.102904.190044

Justo, L. P., \& Calil, H. M. (2006). Depressão: O mesmo acometimento para homens e mulheres? [Depression - does it affect equally men and women?]. Revista de Psiquiatria Clínica, 33(2), 74-79. doi:10.1590/S010160832006000200007

Kennedy, S. H., Einstein, G., \& Downar, J. (2013). Gender/ sex differences in emotions. Medicographia, 35(3), 271280.

Kessler, R. C. (2003). Epidemiology of women and depression. Jounal of Affective Disorders, 74(1), 5-13. doi:10.1016/S0165-0327(02)00426-3

Koppers, D., Peen, J., Niekerken, S., Van, R., \& Dekker, J. (2011). Prevalence and risk factors for recurrence of depression five years after short term psychodynamic therapy. Journal of Affective Disorders, 134(1-3), 468-472. doi:10.1016/j.jad.2011.05.027

Machado, R. M., Oliveira, S. A. B. M., \& Delgado, V. G. (2013). Características sociodemográficas e clínicas das internações psiquiátricas de mulheres com depressão [Sociodemographic and clinical characteristics of psychiatric admissions of women with depression]. Revista Eletrônica de Enfermagem, 15(1), 223-32. doi:10.5216/ ree.v15i1.14564

McCusker, M. G., \& Galupo, M. P. (2011). The impact of men seeking help for depression on perceptions of masculine and feminine characteristics. Psychology of Men and Masculinity, 12(3), 275-284. doi:10.1037/a0021071

Molina, M. A. L., Jansen, K., Drews, C., Pinheiro, R., Silva, R., \& Souza, L. (2014). Major depressive disorder symptoms in male and female young adults. Psychology Health \& Medicine, 19(2), 136-145. doi:10.1080/13548506.201 3.793369

Nardi, B., Francesconi, G., Catena-Del'Osso, M., \& Bellantuono, C. (2013). Adolescent depression: Clinical features and therapeutic strategies. European Review for Medical and Pharmacological Sciences, 17(11), 1546-1551.

Nyer, M. B., Fisher, L. B., \& Farabaugh, A. (2016). Cognitive behavioral therapy for depression. In T J. Petersen, S. E. Sprich, \& S. Wilhelm (Eds.), The Massachusetts General Hospital handbook of cognitive behavioral therapy (pp. 63-86). Totowa, NJ: Humana. 
Parker, G., Blanch, B., \& Crawford, J. (2011). Does gender influence response to differing psychotherapies by those with unipolar depression? Journal of Affective Disorders, 130(1-2), 17-20. doi:10.1016/j.jad.2010.05.020

Picardi, A., \& Gaetano, P. (2014). Psychotherapy of mood disorders. Clinical Practice and Epidemiology in Mental Health, 10, 140-158. doi:10.2174/1745017901410010140

Piccinelli, M., \& Wilkinson, G. (2000). Gender differences in depression. Critical review. The British Journal of Psychiatry, 177(6), 486-492.doi:10.1192/bjp.177.6.486

Rombaldi, A. J., Silva, M. C., Gazalle, F. K., Azevedo, M. R., \& Hallal, P. C. (2010). Prevalência e fatores associados a sintomas depressivos em adultos do sul do Brasil: Estudo transversal de base populacional [Prevalence of depressive symptons and associated factors among Southern Brazilian adults: crosssectional population-based study]. Revista Brasileira de Epidemiologia, 13(4), 620-629. doi:10.1590/S1415-790X2010000400007

Silva, G. D. G., Wiener, C. D., Barbosa, L. P., Araujo, J. M. G., Molina, M. L., San Martin, P., ... Silva, R. A. (2016). Pro-inflammatory cytokines and psychotherapy in depression: Results from a randomized clinical trial. Journal of Psychiatric Research, 75, 57-64. doi:10.1016/j.jpsychires.2016.01.008

Spendelow, J. S. (2015). Cognitive-behavioral treatment of depression in men: Tailoring treatment and directions for future research. American Journal of Men's Health, 9(2), 94-102. doi:10.1177/1557988314529790

Vittengl, J. R., Clark, L. A., Dunn, T. W., \& Jarrett, R. B. (2007). Reducing relapse and recurrence in unipolar depression: A comparative meta-analysis of cognitive-behavioral therapy's effects. Journal of Consulting and Clinical Psychology, 75(3):475-488. doi:10.1037/0022-006X.75.3.475

Whiteford, H. A., Harris, M. G., McKeon, G., Baxter, A., Pennell, C., Barendregt, J. J., \& Wang, J. (2013). Estimating remission from untreated major depression: A systematic review and meta-analysis. Psychological Medicine, 43(8), 1569-1585. doi:10.1017/S0033291712001717

Wilhelm, K., \& Parker, G. (1994). Sex differences in the lifetime prevalence of depression: Fact or artefact? Psychological Medicine, 24(1), 97-111. doi:10.1017/ S0033291700026878

Young, E. A., Kornstein, S. G., Marcus, S. M., Harvey, A. T., Warden, D., Wisniewski, S. R., Balasubramani, G. K., Fava, M., Trivedi, M. H., Rush, A. J. (2009). Sex differences in response to citalopram: A STAR*D report. Journal of Psychiatric Research, 43(5), 503-511. doi:10.1016/j. jpsychires.2008.07.002
Mariane Ricardo Acosta Lopez Molina is Post Doctor of the Graduate Program in Health and Behavior of the Universidade Católica de Pelotas.

Karen Jansen is Professor of the Graduate Program in Health and Behavior of the Universidade Católica de Pelotas.

Ricardo Tavares Pinheiro is Professor of the Graduate Program in Health and Behavior of the Universidade Católica de Pelotas.

Ricardo Azevedo da Silva is Professor of the Graduate Program in Health and Behavior of the Universidade Católica de Pelotas.

Miguel Bezerra dos Passos is psychology student of the Universidade Católica de Pelotas.

Luciano Dias de Mattos Souza is Professor of the the Graduate Program in Health and Behavior of the Universidade Católica de Pelotas.

Received: Feb. 5, 2016

1st Revision: May 24, 2016 Approved: May 26, 2016
How to cite this article:

Molina, M. R. A. L., Jansen, K., Pinheiro, R. T., da Silva, R. A., Passos, M. B., \& Souza, L. D. M. (2017). Depressive symptoms and relationship between genders: Differences in young adults of a randomized controlled trial. Paidéia (Ribeirão Preto), 27(67), 3-9. doi: 10.1590/198243272767201701 